\title{
The New Mongolian State Herder: Examining Invocations and Improvisations of the State in Rural Mongolia
}

\author{
Dr Ariell Ahearn
}

School for Geography and the Environment

University of Oxford

\begin{abstract}
This article aims to advance understandings of contemporary state-making in rural Mongolia, contingent on historical processes rather than a taken-for-granted natural category. Writing on post-socialist Mongolia often emphasizes the 'retreat of the state' in rural areas; this article offers a counterpoint to this discourse by illustrating the ways in which herder livelihoods and idealization of herder labor are actively draw into contemporary state-making practices. Based on ethnographic research in Bayanhongor province, this article examines the interactions between an active local government administration system and pastoralist households at the subdistrict level in rural Mongolia. The analysis focuses on the implementation of two government initiatives tailored for herder households- a State Herder diploma, medal and stamp as well as a government-herder communication notebook. Governmentality studies, performativity theory and the concept of improvisation provide a conceptual framework to argue that the neoliberal 'retreat of the state' in rural Mongolia does not adequately capture the types of state making in the 2010s. Rather, it proposes that scholars should shift attention to how the rural governance
\end{abstract}


works on the ground and focus on the ways in which the state is invoked and made visible in everyday practice with attention to historical legacies.

Keywords: pastoralism, governmentality, improvisation, Mongolia, the state

\section{Introduction}

Six hundred and forty kilometers west of Ulaanbaatar, Erdene's cell phone is constantly ringing, which he juggles between cigarettes and the stick shift of his indefatigable Hyundai Excel. He is the local governor (bagiin darga) of a rural administrative subdistrict called a "bag"1 in Olziit County (sum) in the Central West province of Bayanhongor, Mongolia. In 2013, the bag is home to 189 households who practice mobile pastoralism as their primary livelihood. Erdene is a middle-aged native of the district, a former herder with the energy to match his peppy Bollywood ringtone. In his youth, Erdene envisioned his future work to be as a horse herder for the local socialist collective. Over twenty years since democratic reforms, he works as a public servant for one of the most open economies in Asia. This irony was not lost to him as he sped along the sometimes barely visible track with a confidence that only one with deep knowledge of the landscape could do. It was knowledge built up from a childhood of herding livestock in that area and reinforced by frequent visits to the seasonal camps of local families that his job required.

In Olziit, the everyday work of bag administration is interwoven with family gatherings, friendships, weddings and holidays, herding and rural work, and other everyday routine activities

\footnotetext{
${ }^{1} \mathrm{~A}$ bag is the smallest administrative unit in Mongolia and is a sub-unit of a sum (county), which in turn make up aimag (provinces).
} 
where spending the night with herders while in transit to even-more distant herder homes is often necessary. Government administrative work largely addresses household economic activities, such as buying and selling livestock products, the management of public pastureland, registering households for livestock and social insurance, pension advances, public well repairs, conducting livestock census and other services. Erdene explained with amusement that the Mongolian government is so concerned with livestock that it counts each household's herd twice a year and its human population only once a decade. These counts are recorded on multi-paged spreadsheet printouts featuring each household's livestock profile - neat columns listing numbers of goats, sheep, cows or yaks, horses and camels. Household livestock even act as collateral for bank loans, one reason why Erdene's signature on official counts is in high demand. Each of these administrative events is something of a social event, too, and involves everyday interaction in the space of herder homes, on the phone, or in the cabs of vehicles.

The frequent contact between rural government administrators like Erdene and herding households provides a counterpoint to a number of studies that have portrayed 'the state' as absent in rural areas since the severe economic crises and 'shock therapy' structural adjustment reforms of the 1990s (Fernandez-Gimenez 2002; Fernandez-Gimenez and Batbuyan 2004; Fernandez-Gimenez et al 2012; Upton 2008, 2012; Hannam 2012, 2014; Vindskog 2014). Observations of the active involvement of government administrators like Erdene in everyday herder livelihoods, and herder engagement in local politics illustrates a more complex situation where herder labor and the labor of state-making are closely intertwined. In this case, I argue that a lens which describes the neoliberal 'retreat of the state' in rural Mongolia does not adequately capture this complexity of state-making in the 2010s, about two decades since the initiation of 
structural reforms, de-collectivization and the establishment of capitalism and a democratic system.

In making this argument, this article has two objectives. The first is to shift attention towards how rural governance works in practice on the ground, an approach Dean (2010:37) calls an "analytics of government." This represents a move away from fixing the state as an object and focusing more on the ways in which the state is invoked and made visible in everyday practice with attention to historical legacies. This shift would involve more careful attention to the range of practices, actors, networks, financial flows, and materials which are leveraged in the process of state-making, including how the 'state' as an idea is deployed to advance particular political or developmental ideas. Drawing upon ethnographic fieldwork in rural Bayanhongor, Mongolia from 2012-2014, with follow-up visits in 2017 and 2018, I focus on contemporary forms of state-making by examining two government initiatives involving the distribution of a government-issued 'diploma,' award medal, stamp and an administrative logbook to herders in Bayanhongor province. Using ethnographic vignettes, I illustrate the varying ways in which the idea of the Mongolian state is invoked, performed and improvised by both herders and administrators in this particular region in relation to herder labor, with reference to cultural norms, the socialist past and expectations for democratic governance. Rather than a reified state, 'retreating' in the wake of post-socialist economic crisis and unfettered capitalism, we see in this case a proliferation of actors participating in the contemporary Mongolian state-making project.

The second objective for the article is to interrogate the concept of 'responsibility,' a term often used by herders and administrators in the context of rural governance. I argue that notions of responsibility are not necessarily a straight-forward "responsibilization" in the neoliberal sense of the word (again, associated with state retreat), but draw on antecedent socialist 
frameworks and historical concepts of political membership underpinned by moral concepts around obligation and duty. The process of contemporary responsibilization in the context of contemporary Mongolian state-making might be considered a hybrid of concepts that build upon older forms of political relations and culturally embedded norms related to patron-client relationships.

Attending to the highly social, varied, and improvisational work of administrators like Erdene reveals the importance of historical power relations, moralities and materials through which the idea of the state is invoked and made legible to the rural population. Attention to the critical reflections of local administrators and herders provides an opening to conceptualize the 'governmentalization of the state' (Lemke 2007, p. 46) through the lens of performativity (Jeffrey 2013; Glass and Rose-Redwood 2014; Reeves 2014) and highlights the blurry line between administrators and herders who are sometimes one and the same. A focus on the performative and improvisational aspects through which the state is brought to life puts a greater emphasis on the relational and affective dimensions of power relations as people 'act creatively but within constraints' (Jeffrey 2013). The 'lens of improvisation' (2013: 7), as developed by Alex Jeffrey, provides a foundational point for this analysis. Jeffrey argues that "adopting a lens of improvisation unsettles that concept of the state as a stable backdrop to political life, and instead analysis shifts to the forms of practice, materials and imaginaries that convey particular understandings of the state." This analytical lens helps us to move away from using the concept of 'the state' as a pre-given or natural category. Rather, it focuses on the ways in which statemaking practices are involved in everyday life, livelihoods and politics. In this article, these forms of improvisation clearly connect to herder labor and work practices. In this sense, the improvisations of the state in Mongolia involve not only humans but livestock. 


\section{The State-As-Practice and Its Performative Force}

A significant and growing body of scholarship has problematized the conceptualization of the state as a unified system operating in a sphere separate from society and presiding over a specific territory. Abrams (1988: 76), for example, provocatively asserts that the state is primarily an ideological construction. He states, "The state, then, is not an object akin to the human ear. Nor is it even an object akin to human marriage. It is a third-order object, an ideological project". Abrams argues that the "state-idea" should be studied separately from the “ensemble of institutionalized political power" (1988: 75) that contributes to the continual reproduction of this essentialization of the state. While Abrams separates the idea of the state from 'objects' such as body parts, research that draws more on the work of Foucault and performativity studies emphasizes the mutual constitution of practices and ideas (Lemke 2007; Dean 2010; Glass and Rose- Redwood 2014), "a perspective...that seeks to connect questions of government, politics and administration to the space of bodies, lives, selves and persons" (Dean 2010: 20). In this way, one can say that the ontological status of the state is always partially accomplished through ongoing political processes and relations of power where objects such as 'ears' and 'marriage' are clearly implicated.

Alongside these debates, scholarly attention has focused on the spatial aspects of state organization and production (Reeves 2014; McConnell 2012), with particular focus on transnationalism (Agnew and Corbridge 1995; Ong 1999; Agnew 2005, 2007), territory and territoriality (Gupta 1995; Ferguson and Gupta 2002; Yeh 2013; Steinberg, Tasch and Gerhardt 2014; McConnell 2015), and social organization and development practices (Scott 1998; 
Mitchell 1999; Dean 2010) to name only a few paths of analysis. Scholars have illustrated how bureaucratic practices, ID-documentation, media, public events, religious rituals and other campaigns may blur the lines between imagination and institutions (Taussig 1997; Gordillo 2006; Navaro-Yashin 2012). Navaro-Yashin (2012) calls this a process of "making-andbelieving, or believing and making" to describe the labor of state making and administrative work in Cyprus. While this literature generally agrees that the state is an effect, controversy remains about how the abstraction of the state endures in social practice. Although featuring to some degree in the work of the new materialists and more-than-human geographers, there is an opportunity to further explore the role of animals (in this case, livestock) to problematize the concept of the state.

Foucault's work on power and knowledge has provided a key anchoring point in the problematization of the reified state and scholars' efforts to move beyond the conceptualization of state-society dualism (Jeffrey 2013). An 'analytics of government' framework (Dean 2010; Lemke 2007; Ettlinger 2011), which focuses on "the interplay, the relation between codes of conduct (discourse, mentalities) and on-the-ground regimes of practices" (Ettlinger 2011: 545) has grown out of this work. According to Ettlinger, a range of "techniques of power" connects practices with "codes of conduct (discourses and mentalities)". Ferguson and Gupta (2002: 994) also use a governmentality lens to advance the idea that "mundane bureaucratic practices" such as the work of local inspection agents in an Indian village, normalize and reproduce a metaphorical spatial understanding of the state as being situated above society and surrounding 'local' spheres such as family and community. McConnell's (2015) work provides a fascinating account of the practices of the Tibetan Government-in Exile as they 'rehearse' and perform the state within exiled Tibetan settlements. Despite not having legal authority as 'a state' in India, 
the TGiE uses particular discourses and practices, such as censuses, to construct its exiled population as "a resource under threat in Tibet which therefore needs to be preserved in exile" (2012: 86). This account provides a detailed evidence base to illustrate the range of scales in which state-performance occurs - from eliciting membership from exiled populations to seeking legitimacy and recognition at an international scale.

In moving beyond the state-society dichotomy, scholars such as Rose-Redwood and Glass (2014) have turned to Butler's theory of performativity. Butler defines performativity as "the reiterative and citational practices by which discourse produces the effects that it names" (Butler 1993: 2; also, see Rose-Redwood and Glass 2014: 10). This theory holds that there is not a pre-existing subject or "sovereign" authority, but that subjects are formed through on-going processes of experience, reflection, and re-iteration. As Rose-Redwood and Glass have stated, "it is only through the continuous assertion of sovereign authority that the collective subject we call 'the state' comes into being as a performative effect' (2014: 22). Lemke (2007: 50), drawing on Foucault, echoes this point, "The state is an effect of strategies since it cannot be reduced to a homogeneous, stable actor that exists prior to political action. Rather, the state is to be understood as an emergent and complex resultant of conflicting and contradictory governmental practices.” Recent work by Jeffrey (2013) builds from theories of performance and performativity to develop the idea of the "improvisation of the state." Improvisation captures the sense that people act creatively but also in accordance with their prior knowledge and learning, as well as the resources available to them at a particular time and place. Jeffrey draws upon Bourdieu's notions of social, cultural and economic capital, to show how improvisation is "a process that combines performance and resourcefulness" (2013: 3) attending to questions of agency, individual skills and wider social networks. The concept of improvisation highlights the 
historical contingency of authoritative claim-making and also shows how the basis of these claims change and are re-worked. Improvisation includes the possibility for corruption and deviant claims to authority, recognizing the various means through which authority can be claimed and also contested.

Examining relations between government administrators and herder households in Mongolia, and the social nature of governance as administrators are themselves herders and kin to the local community, provides examples to support the performative terms by which the state idea is made legible in rural Mongolia. The issuing of 'diplomas,' stamps, and medals to herders are styled to mimic socialist era awards and reference former rituals of belonging to the Mongolian polity, but today are based on new socio-economic relations and political expectations in relation to government institutions. These material objects send a message; they provide material to communicate about the state, in critique, praise, or as props for jest. In exploring these initiatives, I make no attempt to make general claims about how government works across all of the administrative districts in Mongolia. Rather, I seek to emphasize the heterogeneity of political practices and technologies which are involved in the production of an abstract collective subject called the state. Given the vast body of literature referred to above, I situate my work with reference to performativity (Jeffrey 2013; Glass and Rose-Redwood 2014; Reeves 2014) and studies of governmentality (Dean 2010; Ettlinger 2011; Brady and Lippert 2016). In doing so, I imagine administrative practices as fundamentally relational, involving material and discursive performances that makes up particular 'political technologies' or 'regimes of practices' that naturalize the state as a collective subject and make it visible in everyday life.

\section{Post-Soviet Improvisations and Relations of Obligation in Rural Mongolia}


The end of the Soviet Union ushered in severe economic crises across its former territories and satellites, creating opportunities for new political formations and actors, such as democracy in Mongolia and Kyrgyzstan, and autocratic regimes in Kazakhstan and Tajikistan. Katherine Verdery, researching in rural Transylvania and Romania, contends that in the final days of the Soviet Union, the socialist system was spatially reorganised through economic reforms such as privatisation, which she refers to as having "de-statizing and re-statizing" effects (1996, p. 215). Privatisation had de-statizing effects because private agencies and individuals became exclusive owners of goods and services formerly available for public use and access. People in positions of authority during the Soviet period were able to transfer their managerial power into ownership power in this transition from public to private ownership of land, factories, housing, etc. Nixson and Walters's (2006) study of the post-1990 privatization process in Mongolia indicates similar trends. People who had 'managerial power' based on occupancy (i.e. apartments in Ulaanbaatar) or were in positions of authority, not only gained more from privatisation, but fared the economic crisis better than those who sold off their shares in this process.

According to Verdery, privatisation also had re-statizing effects because the public demanded central mechanisms for oversight to adjudicate disputes over access to property and employment. Bureaucrats, who were already in advantageous positions within the socialist economy, had insider knowledge, cultural and symbolic capital, and networks to enable them to benefit materially and politically from the privatisation process. They were also in stronger positions to take advantage of and weather fluctuations in the economy, such as periods of unemployment, shortages of basic commodities, shifting prices, and inflation. "Such analysts show that even as entrepratchiks drain the state's assets, thus debilitating the state and changing 
both its capacities and its nature, they also support its continuing existence for the resources and subsidies it provides" (1996, p. 213). In this sense, powerful actors also had interest in certain aspects of re-statization. In this way, the symbols and materials associated with statehood may be considered as a particular type resource for powerful individuals or groups to gain and consolidate political power.

Additionally, anthropological accounts from post-socialist countries highlight how economic crisis and structural adjustments strengthened patronage networks (also prevalent during socialism) and gave rise to Mafia-like organizations. Burawoy and Verdery (1999) write, "The transformation of party states in the context of changes in the global regime of accumulation has radically shifted the rules of the game, the parameters of action within which actors pursue their daily routines and practises. This presents an opportunity for local improvisations that may press either in novel directions or toward a 'return' to socialism... Both innovation and reversion are responses to unstable environments, at least as much as they are evidence of socialism's legacies or its culture" (1999, p. 2). Verdery (1996, p.209) goes so far as to demonstrate how the end of socialism might metaphorically be imagined as a 'return to feudalism' through the 'parcelization and reconstitution of sovereignty' occurring through the de-statizizing and re-statizing effects of privatization and related re-territorialisation of political authority in this process.

In Mongolia, patronage relations, particularly related to norms and moral frameworks around relations of obligation or duty between social groups, have been relevant to historical political relations more broadly. Senior-junior hierarchies (expressed through kinship terms such as 'elder-younger sibling or $a h-d u u)$ are a structuring principle both within family groups as well as patron-client relations more generally (Pedersen 2006, Murphy 2015). Fictive kinship (huurai 
kin), which involves the establishment of close relationships between adults, is formalized in such hierarchies outside of direct family relations (Park 2003). Obligations between seniors and juniors, rulers and subjects, and spirits/gods and humans illustrates a political realm which includes not only bureaucratic institutions but also obligatory relations with more spectral actors such as land spirits and ancestors. Annual mountain worshipping ceremonies conducted by heads of state and members of parliament are a public performance of these relations of obligation, where the political agency is gained through them (Sneath 2014). Ericksen (2014) has analyzed archival material from Southern Bayanhongor to demonstrate how concepts of responsibility draw on past socialist frameworks and feature in contemporary discourses of discipline and hard work around winter disasters called $d z u d$.

The convergence of patronage relations and concepts of kinship have been aspects of post-socialist mutual aid networks which continue to be very much alive in contemporary political allegiances and electoral politics (Radchenko and Jargalsaikhan 2017). In this context, bringing together Dean's 'analytics of government' and Jeffrey's concept of improvisations of the state yields has the potential to yield a more nuanced understanding of the range of actors and resources pulled into new forms of state-making in rural Mongolia's Bayanhongor province.

\section{Administrative Flows in Bayanhongor Province}

[Figure 1 about here]

Figure caption: Map of Mongolia highlighting Bayanhongor province.

This article is based on twelve months of ethnographic fieldwork conducted primarily in Bayanhongor province's centrally-located Olziit sum (county) over the course of 2012-2014, 
with follow-up visits in 2017 and 2018. Bayanhongor province is located in central west Mongolia and is divided into twenty counties. In 2012, the province was home to 23,747 households, of which 10,453 were registered as herder households (National Statistical Office of Mongolia 2013: 220). Olziit county (sum) has a settlement referred to as the sum 'center,' where residences, local government buildings, school, shops, and gas stations are located. Counties are divided into subdistricts (bag), each with a locally elected bag governor (bagiin darga). The county governor and county council governor head the local sum administration and bag governors liaise with these officials as well as clerks, environmental officers, county vets, doctors, police officers and other administrative staff. Herders are officially registered members of a county and a sub-district. Registration status determines voting locations and access to services such as public hospitals and schools. Beyond the sum centre is state-owned pastureland that is home to mobile pastoralists or malchin (herders) and their seasonal encampments.

Olziit is located about twenty kilometers from the Bayanhongor provincial capital. In 2012 the county had 1,021 households registered, 867 of which were herder households. Over the course of this time period, I lived with a middle-aged couple with five grown children in the pastures of one bag in Olziit and participated in all activities of their daily life as herders and members of a large family network. In addition to my primary host family, I stayed with five local herder families of different ages and participated in household activities. Research methods involved participant observation of daily activates, public holidays and important family events (i.e. weddings and births) and writing extensive field-notes, informal interviews, multiple semistructured interviews with 75 herder families in Olziit bag as well as formal interviews with government leaders and employees. Additionally, I attended a number of local government meetings (soum and bag hural) and accompanied the Olziit bag governor on multiple occasions 
during his visits to herder households. This research also involved mapping the seasonal campsites of the herder households registered in the bag in order to investigate mobility, negotiations over winter camp use rights and the organization of rural households. To supplement fieldwork in Olziit, I conducted qualitative fieldwork consisting of participant observation, additional interviewing of herders and local leaders, and observation of local government meetings in Gurvanbulag and Buyanbulag sum in northern Bayanhongor for comparative purposes. I speak Mongolian and all interviews were conducted in the local language. Field notes written in a combination of English and Mongolian alongside transcriptions in the Mongolian language of the semi-structured interviews were analyzed using the qualitative data analysis software ATLAS.ti. Analysis involved coding the interviews and fieldnotes both in the Mongolian and English language to develop thematic categories, which helped to ensure that interpretation was aligned with colloquial meanings. The narratives in this paper include ethnographic vignettes which exemplify a particular category of themes on governance and the concept of 'Mongolian State Herders' (Mongol uulsiin malchin). Triangulation was incorporated into the research methods by follow-up interviews and reading Bayanhongor government publications and Olziit's local government Facebook page, during the fieldwork period.

Due to transportation challenges in the beginning stages of fieldwork (households are located many kilometers apart), my host family suggested that I accompany their bag governor, Erdene, on his rounds in the sub-district. I had frequent contact with bag governors in my other field sites as well as leaders in the provincial government. Erdene is representative of a typical rural bag governor in that he grew up in the bag and had many family relations and childhood school friends among the herder households. Some of these relations take care of his livestock. 
One difference between Erdene and his colleagues is that he has had a long tenure as the bag governor, starting in 2000 and continuing through 2018, and he lives in the Bayanhongor provincial center rather than the sum center. While he had a desk space in the sum government building, his most-used offices were his home, his well-used car, and the homes of herders that we visited.

Administration in rural Mongolia requires almost constant travel between dispersed and mobile seasonal campsites. Bag governors are expected to visit herder homes at seasonal campsites on a frequent basis. Administrative work was determined by environmental or other social and logistical factors. County administrators would often work late into the night to finish compiling reports, and bag governors might be on the road for days to distribute materials or check-in with households. Likewise, herders regularly go to sum or bag centers for meetings to discuss a variety of topics, such as decisions over land tenure rights, pasture, and water use, as well as sum-wide development projects, training seminars, and public budget decisions.

While traveling around the district, we participated in the work of households, helping to sheer sheep, milk goats, herd and water animals, or make dinner. When Erdene began as the bag governor, he traveled by horse and camel to herder homes. His predecessor, a local herder named Dorj, who held the same position during the socialist period, described his job as involving just as much travel, but administration focused on organizing work groups, distributing resources such as hay, and meeting work quotas. Today, the bag governor is charged with the duty of being a liaison between bag herders and the government administration; Erdene described himself as being a zarts or servant for both the government and the herders registered in his bag. The bag governors I was in contact with owned herds, often placed with family or friends living in the district. They are kin to the herders in the sub-district, which is typically their birthplace. In this 
way, government work was something more akin to role playing, where the role of 'darga' may be taken on in one context while the role of uncle/aunt or son-in-law/daughter-in-law may take prevalence in another.

The following sections detail the Bayanhongor government initiatives to highlight the performative element of these political technologies and how they are bound up in contemporary state-making particularly in relation to herder labor and livestock husbandry. It then examines how the Mongolian government, through its bureaucratic practices, enlists herders as 'members' of the state, and to what extent the notion of 'responsibilization' applies in this context.

\section{The New "Mongolian State Herders"}

"A herder is the master of 1000 professions."

-President Elbegdorj, quoted on the top of government-issued herder diplomas, 2013

In the summer of 2013, two new government initiatives were launched in Bayanhongor province. The first initiative took place in June 2013 and consisted of the distribution of an official certificate printed by the Ministry of Labor and Ministry of Agriculture called the "Diploma of the Profession of Herder," an award medal titled "Mongolian State Herder," and a rubber stamp printed with the head of household's name and government registration number. The diploma and award medal were given to all adult registered herders in Olziit, regardless of age or gender. The Government of Bayanhongor Province developed the second initiative, a 'communication notebook,' as a pilot for a national project. The communication notebook is an administrative logbook consisting of a simple lined notebook resembling those used by students in the local schools.

About a week before the presidential election in June 2013, I assisted in the distribution these objects to about 60 herder households the bag where I lived in Olziit County. The official 
diploma for herders was presented in a red plastic padded folder with the title "Mongolian State Herder Diploma" embossed in gold letters in the Mongolian language on the cover. Strikingly, the medal is a replica of the socialist era "Mongolian State Herder" award, featuring the five types of Mongolian livestock in an inverted V shape with the horse at the pinnacle surrounding the Mongolian symbol of state. The stamp featured the name of the head of household and registration number carved into its oval rubber shape. These objects had a strong stylistic resemblance to socialist era materials - the 'stamp', a ubiquitous symbol of bureaucracy; the medal- a reward for good performance in herding; the certificate- a signal of professionalization and modernization.

The diploma, presented alongside the medal, indicates a formalization and symbolic valuing of herder work in the format of an official, government-issued qualification. The certificate was printed in color and divided into two sections. The left side of the page reads (translation from Mongolian):

Diploma of the Profession of Herder

Registration number 0123-46-78910

Tseren Munkhbat of Bayanhongor province's Olziit County

"The professional herder certification is being presented to you in accordance with your mastery of the methods, skills, and knowledge of a herder"

Government registration number 0001"

At the bottom of the left side are the seals and signatures of the Ministers of the Department of Labor and the Department for Agriculture.

The right side of the page reads: 
"This is to certify that Tseren Munkhbat is carrying out and maintaining the traditional practices of animal husbandry of which he has mastered and for which he knows the knowledge and methods."

Following this statement is a list of thirteen points summarizing the knowledge and skills that comprise the work of a herder, including "the skills and knowledge to safeguard the [national] border, language, and livestock," "the ability to work together and labor cooperatively," and "the ability to pass on the traditions and customs." Other points include the ability to make dairy and meat products, to identify livestock qualities such as color, age, and behavior, and the knowledge and ability to market produce. The Herder Diploma cultivates a relationship between central authorities in the government Ministries and herder households, homogenizing herder work and connecting everyday work practices with labors to protect national assets such as "the border, language and livestock." In this way the state as a collective subject becomes legible through herder labor, while herders are enlisted as members by connecting their bodies, mobilities and customs as integral aspects of the Mongolian state identity and its territorial integrity. In this sense, the Herder Diploma can be read as a technique of power with particular disciplining characteristics which relate specifically to herder livelihoods. As Ettlinger (2011: 548) emphasizes, this is not a top-down type of "negative" power, but a productive power which is an interplay between codes of conduct with regimes of practices. Performances of these governmentalities through the distribution of Herder Diplomas, metals and stamps is productive in the sense that it makes the 'state' legible to herders through recognizable symbols and cultural resources. These materials are animated through improvisational relations between administrators and herders in the district, which are described below. 
[Figure 2 about here]

Figure caption: Young herder with his diploma and award metal, standing outside of his ger.

In Olziit, our party of four consisting of the sub-district governor, Erdene, an environmental resource officer, a local university student, and myself distributed the aforementioned objects to the male and female heads of households of the bag. As we traveled over the alternatively sandy and rocky dirt roads of the district, Erdene would call the name of the next family to visit and we would locate their individually wrapped and labeled stamp from a flimsy blue and white plastic bag, tearing at the seams and jammed up on the shelf above the dusty seat of our rattling vehicle. Erdene would quickly fill out the blank spaces on the diploma - the name of the individual, their registration number, the name of the province and county. Erdene even mischievously filled one out for me, complete with a registration number, as a souvenir and what I interpreted as an act of playful resistance, or perhaps acceptance of me as a member of the bag.

After arranging ourselves on the guest side of the one-roomed circular ger (mobile dwelling), exchanging customary greetings and explaining the purpose of our visit over freshly served milk tea, Erdene would gesture for one of us to give the diploma, medal, and stamp to the heads of household. He half-jokingly announced to the herders, "Now you have a profession, congratulations," playing on a common discourse in Mongolia that portrays herders as being without a profession (meregjilgui) and unskilled. The diploma can be seen as source of symbolic capital as formal schooling is associated with 'modern' worldviews and developed (hogjiltei) and cultured (solitoi) subjectivities. Erdene's somewhat sarcastic comments brought into relief the 
connection between contemporary Mongolian state-making and international development discourses around 'modernity,' formal education, and concepts of work and employment based on participation in a market economy.

These items were distributed to every fulltime herding family regardless of age, including elderly people who were still herding in their mid-70s. The families were not expecting to receive the objects and often expressed confusion or asked for instructions on when to use the stamp. The items were often tucked away in locked chests or rested temporarily in a place of honor on the family altar, becoming spatially identified with the most valuable items in the household at the north end of the ger, a space occupied by "higher" objects associated with religion, prosperity, family security, fortune and new gifts. The symbolic qualities of the diploma represent a form of honoring and bestowing value which act as a political instrument and reproduce the perceived authority of the state. At the same time, Erdene's "congratulations" also frames the diploma in a moment of ironic humor or even farce, where the inequalities between countryside and city that this diploma represents become all the more visible. The improvisational encounters between Erdene and the herder households made the 'state' appear quite make-believe, as if Erdene was distributing monopoly money and asking his constituents to play along. Erdene himself- the one most closely resembling a 'state actor' in the traditional sense of the word, was the one pointing out the contradictory and humorous qualities of the situation where he was playing a central role. On one hand, the diploma, with official stamps and signatures from the Ministries, was symbolically profound; on the other it served as a stark reminder of the often exclusionary development narratives where rural investment beyond mining is rare. These narratives have propped up the contemporary Mongolian state-idea (attached to extensive loans and development aid) and help to form the types of 'developed' 
identities that it asks citizens to aspire to and perform. Herders significant investment in tertiary education for their children in Ulaanbaatar is the best example of this dynamic (Ahearn and Bumochir 2016).

The diploma, metal, and stamp contribute to the professionalization and formalization of herder work on paper, while the distribution of these items take on different meanings in the context of ongoing local relations. The diplomas appeal to and reinforce the political discourse that herders play an essential role in maintaining the 'traditional' culture and environment of Mongolia. All three objects include the term "Mongolian State Herder" which emphasizes the role of the herder-as distinct from others (bankers? miners?)-as a particular type of citizen and member of the Mongolian state. These objects invoke the socialist past through the red color and the symbolic qualities of a medal and a stamp, which were ubiquitous materials of socialist government. In 2013, the type of citizenship that they put forth is one based on a framework for pastoralist household production and political participation that categorize herding households as "small and medium enterprises" within a market system rather than Soviet state workers (see Mongolia's Ministry of Industry and Agriculture, for example). While governmentality often draws attention to the political technologies which make the population visible or legible and therefore governable, these materials make the state legible for herders vis-à-vis Mongolian pastoralism, landscape and cultural norms and invite particular forms of improvisation of the state-idea particularly around normative ideas around citizenship. We can see interesting parallels between normative concepts of good citizenship deployed during the socialist period in the form of awards and certificates (i.e. the Honor of Motherhood) (Ahearn 2018) and ways in which similar symbols communicate and simulate particular state-sanctioned identities for rural pastoralists. 
In August 2013, herders in Gurvanbulag County, which is about $240 \mathrm{~km}$ north of Olziit, showed me their diplomas and medals. (I did not take part in the distribution of the diplomas in this area). As I was talking to an older, respected herder in his late 50s, he stood up to show me his long banner of medals hanging from the north side of his ger. He explained many of them to me, but stopped dramatically at the recently distributed Mongolian State Herder medal, a shiny piece at the end of a long display of tarnished socialist awards. "From my medalions, this is the most wonderful. This one. Many people may just disregard it. This is a medal called the Malchin (herder) of Mongolia, with the state coat of arms and so on."

I had not asked a question or referred to the award; he introduced it into the conversation independently. He had received the same metal during the socialist period as well. He explained of the recently distributed award, "They just gave it to a random person like me. Usually, it should have been given with high criteria." Removing the newly acquired medal from the banner, he raised it in the air and said, "It is [important] because it appreciates the fact that malchin consists of a thousand professions in one. Certainly it does! For instance, you can make yogurt in so many ways, you can brew airag [fermented mare's milk] in many other ways. Technology to make eezgii [another dairy product]- Mongolian technology. And then, sewing abundant in its own techniques, using the Mongolian way..." Interestingly, this speech indicates how the 'Mongolian Way' (Mongol yos) is adapted to align with the idea of the Mongolian State through the discourse of herder work. Activities which housholds perform on a daily basis, such as making dairy products, has taken on additional symbolic qualities by connecting household work with the membership in the state and the production of state integrity. 
Other herders appear to be ambivalent towards the diploma and skeptical of its association with the political party in power. These objects may be considered a resource in which ideas of the state are performed and improvised, which occur in herder homes and involve the personal possessions of individuals and their family history, and contribute to their political identity, social status, and values. The objects resonate with the socialist past but offer up a particular vision for herder labor in the contemporary state-making project, labor which is disciplined in particular ways to maintain Mongolian 'customs' and territorial integrity, while also embodying the formal work status of professional market entrepreneurs.

\section{The Communication Notebook}

The "Household Communication Notebook," with the subtitle, 'Bayanhongor Province's Government Logbook" was distributed to herders over the course of 2013. During a public county meeting for herders in Gurvanbulag, the governor of Bayanhongor province held up this notebook and said to the audience:

This official government Household Communication Notebook is in all of the households in the Bayanhongor provincial center and in all of the households in Bayanhongor province. My vision is that at least once-a-season households will make an entry, which can give direction to our work... This book should be developed as a collaboration between citizens and public administrators, and citizens should participate and receive timely access to services, this book can strengthen the conditions for citizen participation and cooperation.

Local government employees, such as doctors, vets, environmental officers, the bag governor, and others use the notebook to log the dates, times, and purpose of their visits to herder homes. The placement of this logbook in herder homes illustrates the expectation that 
government employees make frequent visits to families and maintain a strong relationship with them, and this work should be documented in a formal way. Herder households become administrative spaces where issues such as household finance or the health are sites of active attention. Government services such as health care, for example, were on public display as the district doctor recorded blood pressure and weights, did pregnancy tests, and interviewed women about their birth control choices alongside our other administrative chores in the single-roomed family ger. The government is entangled within the 'relations of obligation' expected by the public from local authorities. The blurring of the line between past forms of patron-client relations and the current market based democracy is captured in the 'service provision' element of the notebook. This can be seen in the contradictory statements of the provincial governor as he described the goal of the notebook:

Our opinion is that the delivery of government services to citizens, in an open and public manner involving citizen participation, is a very important issue. Government services and the work of the state is to provide services for citizens. In our opinion government services were not being delivered and so organized this method to deliver governmental services to the doorstep.

He seemed to contradict this sentiment a few moments later:

People generally complain a lot about their lives: I need this or I need that. Those people need to understand that they can only improve their livelihood by working and by putting some effort into it; otherwise no one is going to do something for you or on your behalf. It is even senseless to expect the government to help in your life. 
I first became aware of the notebook when I traveled with Erdene on his work trips in the fall and winter of 2013. During one work trip, the environmental officer who accompanied us asked each herder to take out their communication notebook in order to log the date and nature of our visit, including a summary of any information discussed. At the visits, herders were encouraged to write their own thoughts, complaints, and suggestions in the notebook. The officer explained to a family, "The aim of keeping this family record book is to exchange information. It is not only to record what we have done but also to get your feedback, complaints and requests." While the majority of herders are literate and most completed primary and secondary school, the written format seemed out of place given herders' practice of face-to-face communication over important issues. Herder suspicions over back-dealings and concerns that written feedback could have negative consequences made the notebook a potentially risky medium of communication. Take, for instance, this exchange between an environmental officer and an older herder during a home visit in the summer of 2013:

Herder: I would like to make a suggestion about the sum activities.

Officer: I'll give you a sheet of paper so please write it on the sheet.

Herder: No, I would like to tell it to you. You are from the sum administration, aren't you?

Officer: Really? Yes, Certainly.

Herder: Why is it that the local administration office allows one person to do two jobs? Officer: Who is doing this?

Herder: Delger makes money working as a garbage collector. He works at the steam boiler at the same time.

Erdene: Please make a note of his feedback. 
Officer: Oh I'll write it down.

Herder: Yes, how is one person allowed to do two jobs? There are so many people who are unemployed.

Officer: Mmmm, yes ok, I'll write it down.

Herder: It is too much. He attends private functions; he makes money for himself. I would like to highlight this. You know, there are many unemployed people around and it's not my intention to have our relatives employed instead of them. My sister, for instance, already has a job now. All these workers from the administration are relatives: look at Agii, for example, she works together with her husband. Now that we live in a democracy, people need to speak up. It's not just me who is big-mouthed. Basically, people who want to be employed need to...

Erdene: Yes, that's true.

Herder: Isn't it the case? You can easily take one of those unemployed and put them to work at the boiler. The administration always talks of supporting poor people. But instead allows one person to do double jobs. That man collects garbage and makes loads of money. Every month he collects 2000 tugrik from each family, and count how many households there are in sum center! It's a lot of money."

Administrative home visits become spaces where herders advocate for their perceived rights based on their history in Olziit and leverage their social roles and perceptions of social hierarchies in a performative way to make these claims. During this exchange, for example, the herder referred to the soum official as her (fictive) younger sibling (minii duu), immediately positioning herself in a position of authority. She spoke in a particular way, melodically drawing out and emphasizing certain words to strengthen her points. Additionally important, during home 
visits the host is in an advantageous social position vis-à-vis the guest, than he or she would be at a public meeting. These are resources that she uses in this improvisational encounter.

In this context, the communication notebook became another administrative logging routine, which was designed to encourage citizen participation and exchange between leaders and rural citizens. As part of the Bayanhongor government's campaign, the notebook is also a political innovation which targets, like the diploma, medal and stamp above, targets herders a particular types of citizens which includes paternal overtones. Occupations such as banking and mining does not seem to have been targeted in this campaign. Herders, however, have been charged to take care of, value, relate to and communicate through the notebook. So far, it is an additional prop in frequent and already existing visits to herder households by county administrators. It has become a part of the 'script' between herders and government administrators and it will be seen to what degree the information logged will be used to facilitate service provision or if it will remain a political symbol used to showcase innovative forms of state-making targeting herder labor in the countryside. The notebook highlights the differing styles of leadership practiced by bag governors and the types of relationships they maintain with households in their district. Although Erdene has little interest in the notebook, his cell phone is constantly ringing with calls from herders in his district. These alternate forms of communication and contact are key ways in which political subjectivity and the organization of government is shaped. Herders solicit people in positions of authority in order to access a range of resources; they do so differently based on their placement in a constellation of relations, including their age, gender, and history of herding in the region. Each person's perception of his or her rights in relation to the administration is different and improvisational, but holds to certain expected norms of communication including hierarchical forms of respect based on concepts of kinship. 


\section{State membership, rights and responsibilization}

The initiatives in Bayanhongor target herders and explicitly address elements of rural pastoralist work practices. They emphasize a relationship between households and individuals as members of the Mongolian polity and invoke the socialist past by framing herders as "state herders." A perfunctory interpretation of the issuing of diplomas and government logbooks to herders inspires a kneejerk critique of neoliberal policies and efforts to responsibilize rural producers. In this section, I suggest that concepts of responsibility, obligation, and duty are frameworks by which the Mongolian government enlists herders as members and active participants in the ongoing production of the contemporary Mongolian state. Development ideologies encapsulate this idea of the Mongolian state-in-the-making, a 'emerging' market on the verge of achieving economic adulthood. These notions of responsibility involve antecedent socialist frameworks and historical concepts of political membership, which are also reflected in the diploma, medal, stamp and government logbook. Given the frequency of critique around neoliberal governance that claims herders are the targets of responsibilization in the absence of the state, how does the notion of responsibilization fit into these instances of local politics and political membership in the Mongolian polity? Is this term applicable to the rural administration and the government initiatives in Bayanhongor? Observations of the relationships between administrators and herders suggest that the moral framework of obligation contributes to the power of the performance of the state idea.

I return briefly to the public sum meeting mentioned above, where the provincial governor emphasized the importance of using the communication notebook. This meeting took place in November 2013 in Gurvanbulag county to discuss sum development and review the government's work of the prior year. The herders and other residents of the sum vigorously 
critiqued the sum governor in moral terms, even likening him to a child that needed training and discipline. A resident of the sum spoke into a microphone placed in the middle of the hall and directly addressed the local government officials:

“I really don't know how you felt about your presentation, or how these people of Governor's office felt about it. However, for a young person like me who lives in this sum, your report has been awful. You shouldn't insult our people by presenting such a report. This work carries responsibility. You should think about how to present your report, and how to prepare for it... I would like to request that you develop yourself and learn to plan ahead before you do the job like this in the future. The reason why I am telling you this is because I am embarrassed at your irresponsibility. You couldn't even read correctly. If you really cannot read, you should have practiced it beforehand to understand it. If so, you wouldn't have made this mistake. This was worse than a 5-yearold boy's writing and presenting."

Prior to this critique, an elder herder stood up and addressed the governor with detailed feedback on his views on giving awards to herders who own more than 1000 livestock, in which he compared the criteria for receiving awards during the socialist time with the current criteria for receiving them today. He felt that the government was devaluing herder work by emphasizing the quantity of herds over the quality. He ended his statement by saying:

"Finally, a few words on duties. These ideas of working hard, or enforcing discipline and responsibility, they are just gone nowadays. No one takes them seriously. For instance, people who work for government or state agencies, regardless of whether that person is doing a good job or a bad job, they are still in their position. Those who work hard need to be rewarded, and those who cannot deliver results, they need to be disciplined, or 
changed. Maybe that way, we can see at least some results. It is just my personal opinion.”

During this meeting, there were other detailed presentations by herders and sum residents that discussed the degenerating moral fiber of the county, the duties and obligations people had to each other in improving the sum and directing resources to the hospital or school in order to make it a more livable place.

Responsibilization has been identified with a particular brand of neoliberal morality that valorizes individual market-based relations (Lemke 2001; Shamir 2008). Responsibilization implies that authoritative bodies, such as NGOs and governments, change the format by which households' access resources, claim rights, and achieve agency by pinning these processes on individual self-initiative through market-based mechanisms. Responsibilization idealizes a separation between state and society, where individuals are responsible for their own self-care and provisioning. The examples from Bayanhongor show a more complex dynamic. State administrators and herders belong to the same community and the boundaries between them are not set, but identities are dependent on the context in which they are performed. Also, while it is the case that there is a powerful discourse around 'being responsible,' which is especially evident in the case of the communication notebook, this initiative marks responsibility between political roles rather than an ushering in of individual market-based model. Unequal access to markets and other resources, is a subject of political debate, but responsibility is often about leadership and morality. It is about the role of authorities to uphold their political responsibility to provide resources that government subjects are not in a place to access. This is akin to the re-statizing practices described by Verdery, where citizens are calling for the return to accepted forms of political engagement with the public. 
The Mongolian government initiatives that link rural identities and practices of mobile pastoralism with membership in the state through "Mongolian State Herder" medals and diplomas, as well as establishing a log book for communication with local administrators offer a glimpse of how improvisations of the contemporary Mongolian state locate involves systems of patron-client relations, which have broader social purchase in the organization of Mongolian society.

\section{Conclusion}

This paper has argued that the collective subject of the state is as an effect and instrument of ongoing political practices, contingent on historical processes rather than a taken-for-granted natural category. It has aimed to shift attention to how rural governance works in practice via an 'analytics of governance' approach and improvisation lens. It further interrogates the concept of 'responsibility' as it connects to historical political subjectivities to suggest that the lens of the neoliberal withdrawal of the state is an inadequate lens for understanding contemporary statesociety relations in rural Bayanhongor. The conceptual lens of improvisation provides a tool to deconstruct the state-society dichotomy, to focus more attention on how the state-idea in a place like rural Mongolia is continually in the process of being re-iterated in new and creative ways in reference to herder labor, the socialist past and moral frameworks around relations of obligation.

A proliferation of materials ties political subjectivities to the state-idea and make the 'state' legible to herders. Recent work on performativity can serve to further hone in on the relations and material conditions that inform this process. As Glass and Rose-Redwood have stated, "it is only through the continuous assertion of sovereign authority that the collective subject we call 'the state' comes into being as a performative effect" (2014: 22). As this paper shows, the continuous assertion of sovereign authority is a messy, emergent and contradictory 
process, often coded into social norms and materials that are borrowed from a range of historical resources. In this particular case in Bayanhongor, we can see the political technologies of the medal, diploma and stamp as making the state legible to a dispersed rural population. In addition to the material aspect of these improvisations, we may give more credit to the creative agency and personalities of certain individuals and the ways in which they emphasize particular archetypal social roles at particular time to achieve political effects. This article alludes to the importance of livestock in improvisations of the state and technologies of government and is a fruitful area for further investigation.

In this paper, the empirical data illustrates the ongoing relevance of historical forms of social organization, in particular antecedent socialist frameworks based on economic participation and good citizenship as well as relations of obligation (Sneath 2007). This perspective provides insight into the links between social hierarchies, pastoralist work practices, and political membership.

By drawing upon ethnographies of rural work practices in Mongolia, this article provides material to help understand some dimensions of rural politics and to move beyond discussions that attempt to measure the degree to which the state is 'there' or 'not there.' Two government initiatives that were implemented over the course of 2013 to analyze how innovative political technologies are used by government institutions to frame concepts of good citizenship and herder labor by recalling and building on past political forms. These items become part of the improvisational encounters between governing authorities and political subjects, as people act with the resources available to them at a given moment. In this way, particular forms of statemaking in these Bayanhongor counties are linked with pastoralist livelihoods and built around 
and in reference to local social contexts and physical environments. Through these materials, the state becomes visible and written into herder labor and social customs.

The performance of administrative roles occurs in the sites of herder homes and points to the multiplicity, variety, and frequency of these events. The two government initiatives described in this paper problematize the notion of responsibilization and its applicability in understanding how government works in rural areas. Rather than a retreat of the state, we see innovative forms of state-making emerging in relation to herder livelihoods and rural administration. Rural administrators do not explicitly advocate market-based models for accessing resources or claiming rights. Rather, discourses on responsibility and irresponsibility have taken shape around citizenship, political participation and citizen expectations for political leadership. It is through these ideas of citizenship and participation that certain development discourses are staged. This can be seen not only in these initiatives, but in public holidays (such as the summer Naadam festival). The government initiatives that specifically target herder households has created a special status for herders as a specific type of subject, which is open to critique by herders as well as the administrators who are charged with playing the role.

Additionally, notions of social disorder and a breakdown in cultural systems of obligation and respect, which are frequently cited by herders as social problems, need to be examined in addition to and beyond conventional neoliberal critiques. Extended research at the local scale in Bayanhongor provides evidence of an administration that was very involved in managing herder affairs with frequent contact via county meetings, phone conversations, home visits and other seasonal events. The bag governors typically grew up in the regions where they work and own livestock. They play multiple roles in the community. The paternal state of the past may have given birth to one with more commercial overtones, which has new modalities of governance 
that deserve further investigation. In both political rationalities, practices of patronage and patron-client relations are features of political improvisations. Patronage is one direction that scholars of the state might pursue in future research, which would yield fruitful conceptualizations of modern systems of power relations and how the idea of the state may be used as a political resource. Valuable work has already been done on this subject in the postsocialist context (Humphrey 2002; Verdery 2003; Alexander, Buchli and Humphrey 2007; Reeves 2014).

This research contains practical implications for the study of the rural economy, systems of government and land use in Mongolia. The initiatives explored suggest that the rural pastoralist economy is moving in the direction of more formalized household enterprises that impact herder political membership and rights to resources. It also indicates that patron-client relations continue to be an important basis for political authority and resource access. This formalization process through the distribution of diplomas and initiatives such as the communication notebook should be seen as part of a wider process of governance and the changing nature of rural work and herders as subjects in Mongolia. This is especially the case as mining takes more land away from herders and resource politics gains traction (Maydar and Jackson 2019). Fine-grained analyses of these processes illustrate that characterization of the state as absent, ineffective, or neglectful in rural areas does not accurately capture the ways in which power is produced and performed through particular governmental rationalities. The extent to which neoliberal means anything to the herders in Bayanhongor, for example, is questionable, yet there are many ways that herders and close attention to their political lives can enhance our understanding of governance that deserves sensitive attention. 


\section{Acknowledgements}

Sincere thanks to the people of Olziit and Byanhongor province for their support and continued friendship. I am grateful to Dawn Chatty, Craig Jeffrey and Troy Sternberg for providing comments on early drafts of this paper. Additionally, special thanks to Aoife Haney, Stefania Innocenti, Radhika Kosla, and Caitlin McElroy for the inspiration to write. Finally, my sincerest appreciation goes to the three anonymous reviewers for their rigorous comments and to Nik Heyden for his editorial insights. Any mistakes are mine alone.

\section{Author Biography}

Ariell Ahearn is the course director of the MSc/MPhil Programme in Nature, Society and Environmental Governance at the School for Geography and the Environment at the University of Oxford. Her research interests include mobile pastoralism, the state and environmental governance, and social change in rural Mongolia and Inner Asia.

\section{References}

Abrams, P. 1998. Notes on the Difficulty of Studying the State. Journal of Historical Sociology 1(1): 58-87.

Agnew, J. 2005. Sovereignty Regimes: Territoriality and State Authority in Contemporary World Politics. Annals of the Association of American Geographers 95(2): 437-461. 
2007. No Borders, No Nations: Making Greece in Macedonia. Annals of the Association of American Geographers 97(2): 398-422.

Agnew, J., and S. Corbridge. 1995. Mastering Space: Hegemony, Territory, and International Political Economy. London: Routledge.

Ahearn, Ariell. "A Condensed History of the Public Administration of Pastoralism in Mongolia." Nomadic Peoples22.2 (2018): 282-303.

Alexander, C., Buchli, V., and C. Humphrey, eds. Urban life in post-Soviet Asia. CRC Press, 2007.

Atwood, C. P. 2012. Banner, Otog, Thousand: Appanage Community as the Basic Unit of Traditional Mongolian Society. Mongolian Studies 34: 1-76.

Butler, J.. "Bodies That Matter: On the Discursive Limits of "Sex."." New York and London: Routledge (1993).

Brady, M. and R. K. Lippert. 2016. Governing Practices: Neoliberalism, Governmentality and the Ethnographic Imaginary. Toronto: University of Toronto Press.

Dean, M. 2010. Governmentality: Power and Rule in Modern Society, second edition. Los Angeles: Sage. 
Ericksen, A. 2014. Depend on Each Other and Don't Just Sit: The Socialist Legacy, Responsibility, and Winter Risk among Mongolian Herders. Human Organization 73(1): 38-49.

Ettlinger, N. 2011. Governmentality as Epistemology. Annals of the Association of American Geographers, 101 (3), 537-560, DOI: 10.1080/00045608.2010.544962

Ferguson, J., and A. Gupta. 2002. Spatializing States: Towards an Ethnology of Neoliberal Governmentality. American Ethnologist 29 (4): 981-1002.

Fernandez-Gimenez, M. E. 2002. Spatial and Social Boundaries and the Paradox of Pastoral Land Tenure: A Case Study from Post-Socialist Mongolia. Human Ecology 30(1): 49.

Fernandez-Gimenez, M. E., and B. Batbuyan. 2004. Law and Disorder: Local Implementation of Mongolia's Land Law. Development and Change 35(1): 141-165.

Fernandez-Gimenez, Maria E., W. Xiaoyi, B. Batkhishig, J. A. Klein, and R. S. Reid, eds. 2012. Restoring Community Connections to the Land. Wallingford, UK: CABI.

Glass, M. R., and R. Rose-Redwood, eds. 2014. Performativity, Politics, and the Production of Social Space. New York: Routledge. 
Gordillo, G. 2006. The Crucible of Citizenship: ID Paper Fetishism in the Argentinean Chaco. American Ethnologist 33(2): 162-176.

Gupta, A. 1995. Blurred Boundaries: The Discourse of Corruption, the Culture of Politics, and the Imagined State. American Ethnologist 22(2): 375-402.

Hannam, I. 2012. International Perspectives on Legislative and Administrative Reforms as an Aid to Better Land Stewardship. In Rangeland Stewardship in Central Asia. Springer Netherlands.

2014, Legal and Policy Aspects of Rangeland management-Mongolia. In The Governance of Rangelands: Collective Action for Sustainable Pastoralism, p. 156

Humphrey, C. 2002. The Unmaking of Soviet Life: Everyday Economies After Socialism. Ithaca: Cornell University Press.

Jeffrey, A. 2013. The Improvised State: Sovereignty, Performance and Agency in Dayton, Bosnia. Malden: Wiley-Blackwell.

Lemke, T. 2001. The Birth of Bio-Politics: Michel Foucault's Lecture at the College de France on Neoliberal Governmentality. Economy and Society 30(2): 190-207. 
2007. An indigestible meal? Foucault, governmentality and state theory. Distinktion: Journal of Social Theory 8 (2): 43-64.

Myadar, Orhon, and Sara Jackson. "Contradictions of populism and resource extraction: Examining the intersection of resource nationalism and accumulation by dispossession in Mongolia." Annals of the American Association of Geographers 109.2 (2019): 361-370.

McConnell, F. 2012. Governmentality to Practice the State? Constructing a Tibetan Population in Exile. Environment and Planning D: Society and Space 30: 78-95.

2015. Rehearsing the State: The Political Practices of the Tibetan Government-in-Exile. John Wiley \& Sons.

Myadar, O., \& Jackson, S. (2018). Contradictions of Populism and Resource Extraction: Examining the Intersection of Resource Nationalism and Accumulation by Dispossession in Mongolia. Annals of the American Association of Geographers, 1-10.

Mitchell, T. 1999. Society, Economy, and the State Effect. In State/Culture: State-Formation after the Cultural Turn. 76-97. Ithaca: Cornell University Press.

Murphy, D. J. 2014. Ecology of Rule: Territorial Assemblages and Environmental Governance in Rural Mongolia. Anthropological Quarterly 83(3): 759-792. 
2015. From Kin to Contract: Labor, Work, and the Production of Authority in Rural Mongolia. The Journal of Peasant Studies 42(2): 397-424.

National Statistical Office of Mongolia. 2012.

National Statistical Yearbook. http://www.1212.mn/en/, accessed May 10, 2015.

Navaro-Yashin, Y. 2012. The Make-Believe Space: Affective Geography in a Postwar Polity.

Durham: Duke University Press.

Nixson, F., and Walters, B. (2006) Privatization, Income Distribution, and Poverty: The Mongolian Experience. World Development, 34 (9), 1557-1579.

Ong, A. 1999. Flexible Citizenship: The Cultural Logic of Transnationality. Durham: Duke University Press.

Park, H-Y. (2003) Metaphorical and Ideological Concepts of Post-Socialist Mongolian Kinship. Inner Asia, 5 (2), 143-62.

Pedersen, M. A. 2006. Where Is the Center? The Spatial Distribution of Power in Post-Socialist Rural Mongolia. In: O. Bruun and L. Narangoa (eds.) Mongols from Country to City: Floating Boundaries, Pastoralism and City Life in the Mongol Lands. 82-109. Copenhagen: Nordic Institute of Asian Studies. 
Reeves, M. 2014. Border Work: Spatial Lives of the State in Rural Central Asia. Ithaca: Cornell University Press.

Scott, J. C. 1998. Seeing like a State: How Certain Schemes to Improve the Human Condition Have Failed. New Haven; London: Yale University Press.

Shamir, R. 2008. The Age of Responsibilization: On Market-Embedded Morality. Economy and Society 37(1): 1-19.

Sneath, D. 2007. The Headless State: Aristocratic Orders, Kinship Society, and Misrepresentations of Nomadic Inner Asia. New York: Columbia University Press.

2010. Political Mobilization and the Construction of Collective Identity in Mongolia. Central Asia Survey 29(3): 251-267.

2014. Nationalising civilization resources: sacred mountains and cosmopolitical ritual in Mongolia. Asian Ethnicity. 15 (4): 458-472.

Steinberg, P. E., J. Tasch, and H. Gerhardt. 2015. Contesting the Arctic: Politics and Imaginaries in the Circumpolar North. London: I.B. Tauris.

Taussig, M. 1997. The Magic of the State. New York: Routledge. 
Upton, C. 2008. Social Capital, Collective Action and Group Formation: Developmental Trajectories in Post-Socialist Mongolia. Human Ecology 36(2): 175-188.

2012. Managing Mongolia's Commons: Land Reforms, Social Contexts, and Institutional Change. Society \& Natural Resources: An International Journal 25(2): 156-175.

Verdery, K. (1996). What was socialism, and what comes next? (Princeton studies in culture/power/history). Princeton, N.J.: Princeton University Press.

2003. The Vanishing Hectare: Property and Value in Postsocialist Transylvania. Ithaca: Cornell University Press.

Vindskog, B. V. 2014. Natural Calamities and 'the Big Migration': the Challenges to the Mongolian health system in the 'Age of the Market', Global Public Health 9 (8): 880-893.

Yeh, E. T. 2013. Taming Tibet: Landscape Transformation and the Gift of Chinese Development. Ithaca: Cornell University Press. 